\title{
Physicochemical and Spectroscopic Characteristics of Biofield Treated $p$-Chlorobenzophenone
}

\author{
Mahendra Kumar Trivedi ${ }^{1}$, Alice Branton ${ }^{1}$, Dahryn Trivedi ${ }^{1}$, Gopal Nayak ${ }^{1}$, Khemraj Bairwa ${ }^{2}$, \\ Snehasis Jana ${ }^{2^{*}}$ \\ ${ }^{1}$ Trivedi Global Inc., Henderson, NV, USA \\ ${ }^{2}$ Trivedi Science Research Laboratory Pvt. Ltd., Bhopal, Madhya Pradesh, India
}

Email address:

publication@trivedisrl.com (S. Jana)

\section{To cite this article:}

Mahendra Kumar Trivedi, Alice Branton, Dahryn Trivedi, Gopal Nayak, Khemraj Bairwa, Snehasis Jana. Physicochemical and Spectroscopic Characteristics of Biofield Treated p-Chlorobenzophenone. American Journal of Physical Chemistry. Vol. 4, No. 6, 2015, pp. 48-57. doi: 10.11648/j.ajpc.20150406.12

\begin{abstract}
Chlorobenzophenone ( $p$-CBP) is the important chemical intermediate used for the synthesis of several pharmaceutical drugs like fenofibrate, cetirizine, alprazolam, and benzodiazepine. The aim of this study was set to evaluate the impact of biofield energy treatment on physicochemical and spectroscopic properties of $p$-CBP. The study was accomplished in two groups i.e. control and treated. The treated group was subjected to Mr. Trivedi's biofield energy treatment. Subsequently, the control and treated samples of $p$-CBP were analyzed using X-ray diffraction (XRD), particle size analyzer, surface area analyzer, differential scanning calorimetry (DSC), thermogravimetric analysis-derivative thermogravimetric analysis (TGA-DTG), Fourier transform infrared (FT-IR), and ultraviolet-visible (UV-Vis) spectroscopy. The XRD study exhibited the increase in average crystallite size $(25.93 \%)$ as well as the intensity of XRD peaks of treated $p$-CBP, as compared to the control. The particle size analysis showed the reduction in particle size of fine particles $(\leq 51.49 \mu \mathrm{m})$ by $21.6 \%\left(\mathrm{~d}_{10}\right)$, whereas, increase in particle size of large particles $(\geq 433.59 \mu \mathrm{m})$ by $12.82 \%\left(\mathrm{~d}_{90}\right)$ and $17.71 \%\left(\mathrm{~d}_{99}\right)$, respectively after biofield treatment, as compared to the control. The surface area analysis exhibited the surface area as $0.7005 \mathrm{~m}^{2} / \mathrm{g}$ in control and 0.7020 $\mathrm{m}^{2} / \mathrm{g}$ in treated sample of $p$-CBP. The DSC thermogram of treated $p$-CBP exhibited the slight decrease in melting temperature. However, the latent heat of fusion was significantly altered (24.90\%) after biofield energy treatment as compared to the control. TGA analysis showed the weight loss by $57.36 \%$ in control and $58.51 \%$ in treated sample. In addition, the onset temperature of thermal degradation was also decreased by $6.32 \%$ after biofield energy treatment as compared to the control $p$ CBP. The FT-IR and UV spectroscopic study did not show the alteration in the wavenumber and wavelength, respectively in treated $p$-CBP as compared to the control. Altogether, the XRD, particle size and thermal analysis suggest that biofield energy treatment has significant impact on physical and thermal properties of treated $p$-CBP.
\end{abstract}

Keywords: $p$-Chlorobenzophenone, Biofield Treatment, X-ray Diffraction, Particle Size Analysis, Differential Scanning Calorimetry, Thermogravimetric Analysis

\section{Introduction}

Benzophenones (diphenyl ketones) are the important compounds and refer to all types of substituted benzophenone. They are widely used in organic synthesis of several pharmaceutical drugs like anxiolytic, hypnotic and antihistaminic. Benzophenone is also used as the starting material for dyes, pesticides and natural products $[1,2]$. It has rose-like odor, therefore used in the preparation of synthetic perfumes. Benzophenones are used as a photoinitiator of UV-curing applications in inks, optical fibers, adhesive, coatings, and in printed circuit boards [3]. Photoinitiators are compounds, which break down into free radicals upon ultraviolet radiation exposure. The cosmetic grade benzophenone is used in sunscreen to reduce skin damage by blocking UV radiations i.e. UV-A $(320-400 \mathrm{~nm})$ and UV-B (290-320 nm) [4]. Benzophenones are also known to be pharmacologically active and reported as DNA photosensitizers [5]. Based on the importance of benzophenone as a chemical intermediate for organic synthesis of pharmaceutical drug. It is advantageous to find out the alternate approach that can enhance the 
physicochemical and thermal properties of $p$ chlorobenzophenone ( $p$-CBP). Recently, biofield energy treatment was reported to alter the physicochemical and thermal properties of several metals $[6,7]$ and ceramics $[8$, 9]; and spectroscopic properties of various pharmaceutical drugs like chloramphenicol, tetracycline, paracetamol, and piroxicam $[10,11]$.

The National Institute of Health/National Center for Complementary and Alternative Medicine (NIH/NCCAM) considered the biofield energy therapy (therapy) in subcategory of energy therapies (putative energy fields) [12, 13]. The biofield energy treatment has been used in healing process to reduce pain, anxiety and to promote the overall health of human being [14, 15]. According to the Maxwell JC, the every vibrant process in the human body has an electrical significance that generates magnetic field in the human [16]. This electromagnetic field of the human body is known as the biofield and energy associated with this field is termed as the biofield energy [17, 18]. Prakash et al. reported that various scientific instruments such as Kirlian photography, resonance field imaging (RFI) and polycontrast interference photography (PIP) can be extensively used to measure the biofield of human body [19]. Thus, the human has the ability to harness the energy from the environment or Universe and transmit this energy to any living or nonliving object on the Globe. The object(s) receive the energy and respond into useful way; this process is termed as biofield treatment. Mr. Trivedi's unique biofield energy is known as The Trivedi Effect ${ }^{\circledR}$. Recently, the biofield energy treatment has been evaluated in several fields like biotechnology [20], microbiology $[21,22]$, material science [6-9], and agricultural science [23, 24].

Based on the published literature and outstanding impact of biofield energy treatment on various living and nonliving things, the present study was aimed to evaluate the impact of biofield energy treatment on physicochemical and spectroscopic properties of $p$-CBP using various analytical techniques.

\section{Materials and Methods}

\subsection{Study Design}

p-Chlorobenzophenone was procured from Sisco Research Laboratories, India. The study was carried out in two groups i.e. control and treatment. The control sample was remained as untreated; and treatment sample was handed over in sealed pack to Mr. Trivedi for biofield energy treatment under laboratory conditions. Mr. Trivedi rendered the biofield energy treatment through his unique energy transmission process i.e. thought transmission to the treatment group without touching the sample. After the biofield treatment, both the control and treated samples of $p$-CBP were analyzed using various analytical techniques like the $\mathrm{X}$-ray diffractometry (XRD), particle size analyzer, surface area analyzer, differential scanning calorimetry (DSC), thermogravimetric analysis (TGA), Fourier transform infrared (FT-IR), and ultraviolet-visible (UV-Vis) spectroscopy.

\subsection{XRD Study}

XRD analysis of $p$-CBP was carried out on Phillips, Holland PW 1710 X-ray diffractometer with nickel filter and copper anode. X-ray wavelength used in XRD system was $1.54056 \AA$. The XRD diffractogram was obtained in the form of a chart of $2 \theta v s$. intensity. The average crystallite size (G) and percent change in average crystallite size of $p$-CBP were calculated using the following equations [25].

$$
\text { Average crystallite size }(G)=k \lambda /(b \operatorname{Cos} \theta)
$$

Percent change in average crystallite size $(\mathrm{G})$

$$
=\left[\left(\mathrm{G}_{\mathrm{t}}-\mathrm{G}_{\mathrm{c}}\right) / \mathrm{G}_{\mathrm{c}}\right] \times 100
$$

Where, $G_{c}$ and $G_{t}$ are average crystallite size of control and treated powder samples respectively.

\subsection{Particle size Analysis}

The particle size of control and treated $p$-CBP was determined using laser particle size analyzer Sympatec HELOS-BF, with detection range of $0 \cdot 1-875 \mu \mathrm{m}$. The particle size data were collected in the form of a chart of particle size $v s$. cumulative percentage. The particle sizes i.e. $\mathrm{d}_{10}, \mathrm{~d}_{50}, \mathrm{~d}_{90}$, and $\mathrm{d}_{99}$ (size below which $10 \%, 50 \%, 90 \%$, and 99\% particles are present, respectively) were computed from the particle size distribution curve. The percentage change in particle size was calculated with the help of following equation.

$$
\begin{gathered}
\% \text { change in particle size, } \mathrm{d}_{10} \\
=\frac{\left[\left(d_{10}\right) \text { Treated }-\left(d_{10}\right) \text { Control }\right]}{\left(d_{10}\right) \text { Control }} \times 100
\end{gathered}
$$

Where, $\left(\mathrm{d}_{10}\right)_{\text {Control }}$ and $\left(\mathrm{d}_{10}\right)$ Treated are the particle size $\mathrm{d}_{10}$ of control and treated samples respectively. Accordingly, the percent changes in particle size i.e. $\mathrm{d}_{50}, \mathrm{~d}_{90}$, and $\mathrm{d}_{99}$ were calculated.

\subsection{Surface Area Analysis}

Surface area of control and treated $p$-CBP was measured using the Brunauer-Emmett-Teller (BET) surface area analyzer, Smart SORB 90. Percent change in surface area was calculated using following equation:

$$
\% \text { change in surface area }=\frac{\left[\mathrm{S}_{\text {Treated }}-\mathrm{S}_{\text {Control }}\right]}{\mathrm{S}_{\text {Control }}} \times 1004
$$

Where, $\mathrm{S}_{\text {Control }}$ and $\mathrm{S}_{\text {Treated }}$ are the surface area of control and treated samples, respectively.

\subsection{DSC Study}

The control and treated samples of $p$-CBP were studied using a Pyris-6 Perkin Elmer differential scanning calorimeter on a heating rate of $10^{\circ} \mathrm{C} / \mathrm{min}$ under air atmosphere with air flow rate of $5 \mathrm{~mL} / \mathrm{min}$. An empty pan 
sealed with cover was used as a reference pan. The melting temperature $\left(\mathrm{T}_{\mathrm{m}}\right)$ and latent heat of fusion $(\Delta \mathrm{H})$ were obtained from the DSC curve.

\subsection{TGA-DTG Analysis}

The effect of biofield energy treatment on thermal properties of control and treated $p$-CBP were studied using Mettler Toledo simultaneous TGA-DTG. The samples were heated up to $400^{\circ} \mathrm{C}$ from room temperature at the heating rate of $5^{\circ} \mathrm{C} / \mathrm{min}$ under air atmosphere. The onset temperature at which thermal degradation starts and percent change in temperature at which maximum weight loss occurs in sample were acquired from DTG thermogram.

\subsection{Spectroscopic Studies}

For the purpose of FT-IR and UV-Vis spectroscopic characterization, the treated sample was divided into two groups i.e. $\mathrm{T} 1$ and $\mathrm{T} 2$. Both treated groups were separately analyzed for their spectroscopic characteristics using FT-IR and UV-Vis spectroscopy and data were compared with the respective spectrum of control $p$-CBP sample.

\subsubsection{FT-IR Spectroscopic Characterization}

FT-IR spectra of control and treated samples of $p$-CBP were obtained from Shimadzu's Fourier transform infrared spectrometer (Japan) with the frequency range of 4000-500 $\mathrm{cm}^{-1}$. The analysis was accomplished to evaluate the impact of biofield energy treatment at atomic level like force constant, dipole moment, and bond strength in chemical structure [26].

\subsubsection{UV-Vis Spectroscopic Analysis}

UV spectra of control and treated samples of $p$-CBP were acquired from Shimadzu UV-2400 PC series spectrophotometer. Quartz cell with $1 \mathrm{~cm}$ and a slit width of $2.0 \mathrm{~nm}$ were used for analysis. The study was carried out at wavelength in the region of 200-400 $\mathrm{nm}$. The UV spectra were analyzed to find out the effect of biofield energy treatment on the energy gap of highest occupied molecular orbital and lowest unoccupied molecular orbital (HOMOLUMO gap) [26].

\section{Results and Discussion}

\subsection{XRD Analysis}

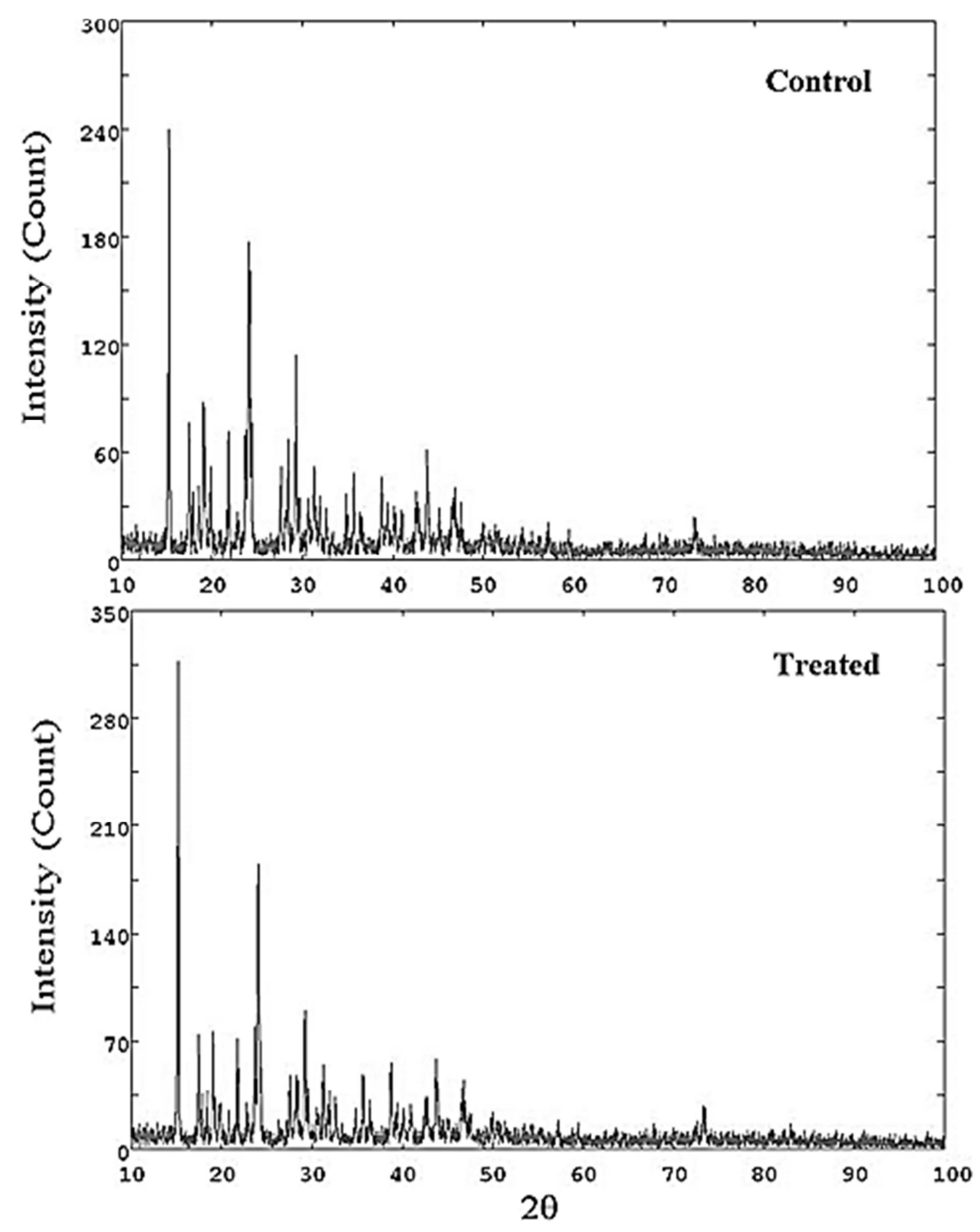

Fig. 1. XRD diffractograms of p-chlorobenzophenone. 
XRD diffractograms of control and treated $p$-CBP are shown in Fig. 1. The control $p$-CBP exhibited the XRD peaks at $2 \theta$ equal to $15.25^{\circ}, 17.47^{\circ}, 19.04^{\circ}, 21.82^{\circ}, 23.72^{\circ}, 24.08^{\circ}$, $28.41^{\circ}$, and $29.27^{\circ}$. However, the XRD diffractogram of treated $p$-CBP showed the XRD peaks at $2 \theta$ equal to $15.22^{\circ}$, $17.48^{\circ}, 19.04^{\circ}, 21.76^{\circ}, 23.66^{\circ}, 24.03^{\circ}, 29.21^{\circ}$, and $31.27^{\circ}$, with increased intensity of XRD peaks as compared to the control. The sharp peaks in XRD diffractogram of both control and treated samples suggest the crystalline nature of $p$-CBP. The increase in intensity of XRD peaks in treated sample may be attributed to enhanced crystallinity as compared to the control. It is assumed that treated $p$-CBP molecules absorbed biofield energy that may lead to formation of long-range symmetrical crystalline pattern as compared to the control sample.

The average crystallite size was calculated using Scherrer formula and the results are shown in Fig. 2. The average crystallite size of control $p$-CBP was found as $83.18 \mathrm{~nm}$ that was increased to $104.75 \mathrm{~nm}$ in treated sample. The result showed about $25.93 \%$ increase in average crystallite size in treated sample as compared to the control.

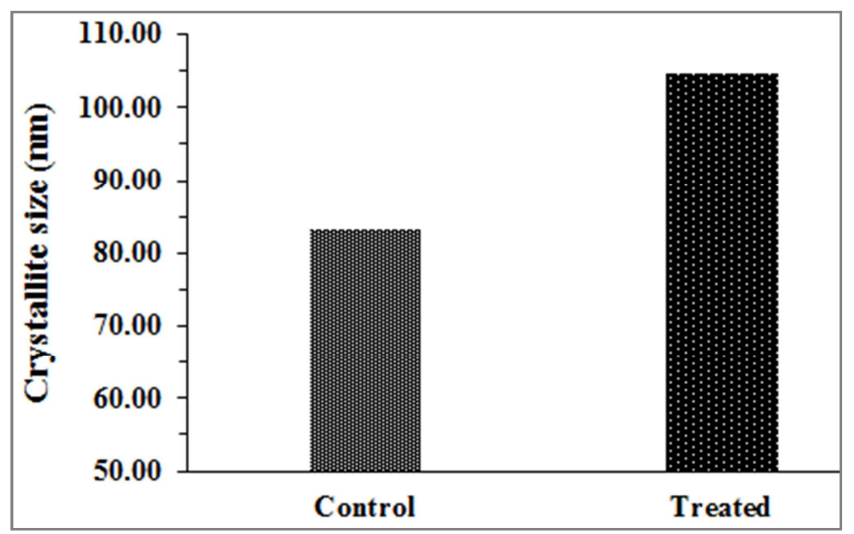

Fig. 2. Crystallite size of control and treated p-chlorobenzophenone.

The role of temperature on average crystallite size is well reported in the literature, which indicates that increase in temperature reduces the thermodynamically driven force. This leads to decrease in nuclear densities and thus increase in average crystallite size [27, 28]. Moreover, Gaber et al. described that elevation in processing temperature causes to decrease in dislocation density and increase in number of unit cell, which finally increased the average crystallite size [29]. Based on these, it is assumed that biofield energy treatment may provide the energy to $p$-CBP that causes decrease in dislocation density and increase in average crystallite size.

\subsection{Particle Size Analysis}

The particle size was determined in four groups i.e. $\mathrm{d}_{10}$, $\mathrm{d}_{50}, \mathrm{~d}_{90}$, and $\mathrm{d}_{99}$ (size below which $10 \%, 50 \%, 90 \%$, and $99 \%$ particles are present, respectively) and result are presented in Fig. 3. The particle size result showed $d_{10}, d_{50}, d_{90}$, and $d_{99}$ as $51.49,160.15,433.59$, and $588.07 \mu \mathrm{m}$, respectively in control sample, which were converted to 40.37 , 157.66,
489.16, $692.19 \mu \mathrm{m}$, respectively after biofield treatment. The results suggest that $d_{10}$ and $d_{50}$ particle sizes were decreased by $21.60 \%$ and $1.55 \%$ in treated $p$-CBP as compared to the control.

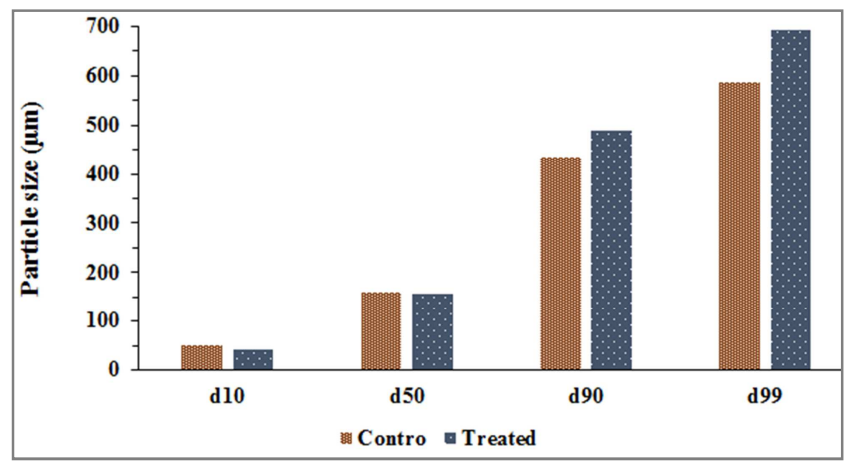

Fig. 3. Particle size analysis of control and treated p-chlorobenzophenone.

On the contrary, the $\mathrm{d}_{90}$ and $\mathrm{d}_{99}$ were found to increase up to $12.82 \%$ and $17.71 \%$, in treated $p$-CBP respectively with respect to the control. The reduction of $\mathrm{d}_{10}$ and increase of $\mathrm{d}_{90}$ could be possible if fracturing and agglomeration took place simultaneously in treated $p$-CBP. Recently, our group reported the effect of biofield energy treatment on the particle size of manganese oxide [8]. It was described that finer particles get agglomerated after biofield energy treatment and lead to increase the percent of larger particle size. Thus, it is assumed that the energy, probably transferred through biofield treatment, might induce fracturing and agglomeration process in treated $p$-CBP, which resulted into alteration in particle sizes. Altogether, the result exhibited the alteration in the particle size of $p$ CBP after biofield treatment.

\subsection{Surface Area Analysis}

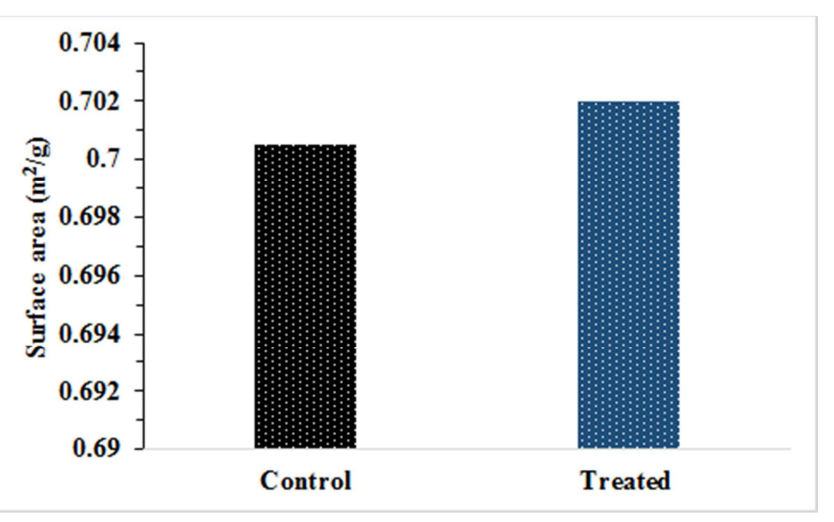

Fig. 4. Surface area analysis of control and treated p-chlorobenzophenone.

The surface areas of control and treated samples of $p$ CBP were determined using BET surface area analyzer and data are presented in Fig. 4. The control sample showed a surface area of $0.7005 \mathrm{~m}^{2} / \mathrm{g}$; however, the treated sample showed a surface area of $0.7020 \mathrm{~m}^{2} / \mathrm{g}$. The result showed a slight increase in surface area $(0.21 \%)$ in the treated $p$-CBP as compared to the control. The increase in surface area 
might be correlated to particle size reduction in fine particle region due to high internal strain produced by biofield energy treatment [30]. The increase in surface area may lead to increase in solubility and reactivity of $p$-CBP as compared to the control.

\subsection{DSC Analysis}

DSC analysis was performed to determine the melting temperature and latent heat of fusion $(\Delta \mathrm{H})$ of control and treated $p$-CBP. In solid substance, an ample amount of interaction force exists in atomic bonds that hold the atoms at their positions. The energy required to overcome the interaction force of phase change i.e. solid into liquid is known as latent heat of fusion. DSC thermogram (Fig. 5) of $p$-CBP showed the melting temperature at $77.57^{\circ} \mathrm{C}$ in control and $76.82^{\circ} \mathrm{C}$ in treated sample (Table 1 ).
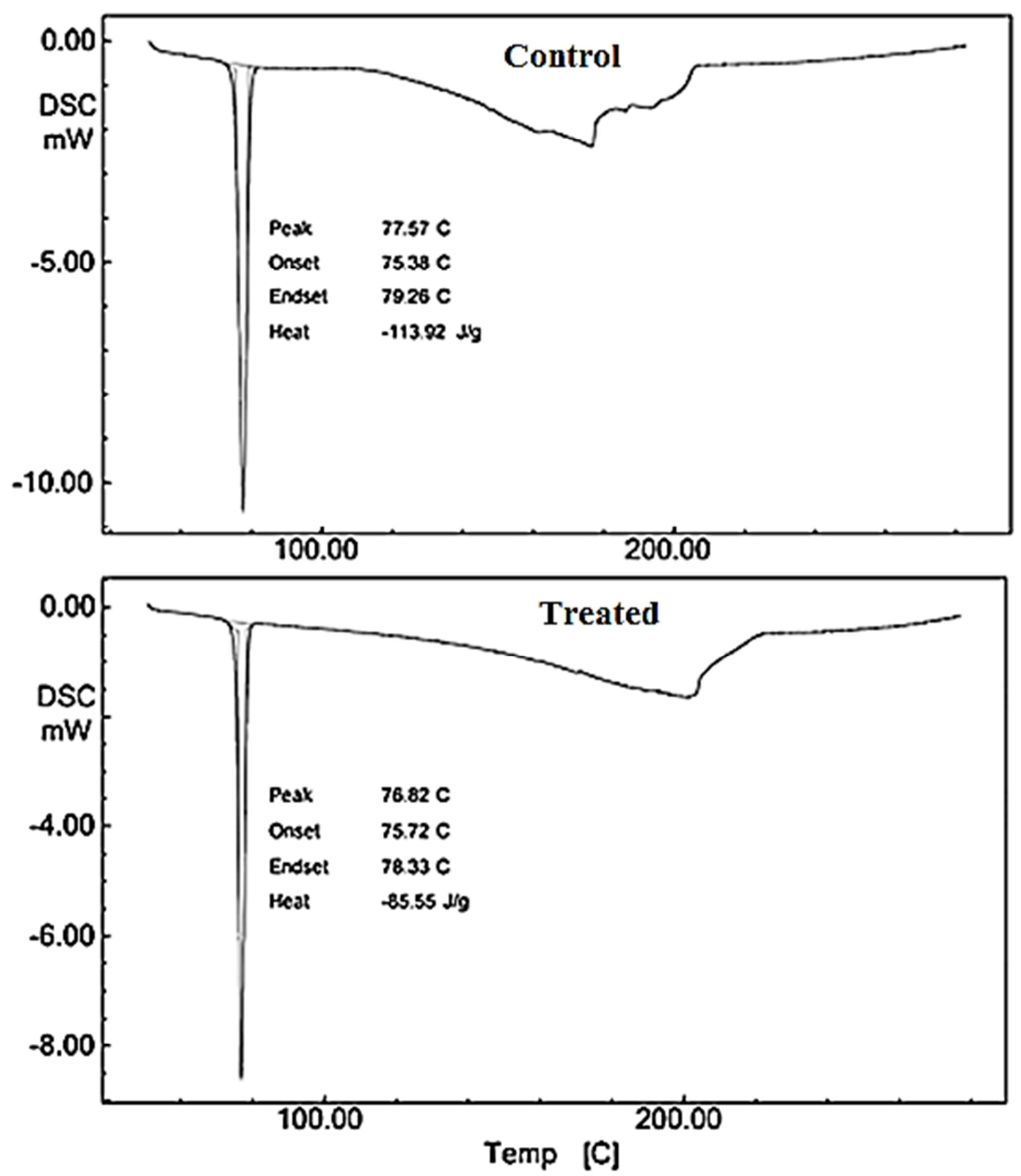

Fig. 5. DSC thermograms of control and treated p-chlorobenzophenone.

Table 1. Thermal analysis of control and treated samples of pchlorobenzophenone.

\begin{tabular}{lll}
\hline Parameter & Control & Treated \\
\hline Latent heat of fusion $(\mathrm{J} / \mathrm{g})$ & 113.92 & 85.55 \\
Melting point $\left({ }^{\circ} \mathrm{C}\right)$ & 77.57 & 76.82 \\
Onset temperature $\left({ }^{\circ} \mathrm{C}\right)$ & 190 & 178 \\
End-set temperature $\left({ }^{\circ} \mathrm{C}\right)$ & 230.5 & 238 \\
$\mathrm{~T}_{\max }\left({ }^{\circ} \mathrm{C}\right)$ & 207.51 & 206.33 \\
\hline
\end{tabular}

$\mathrm{T}_{\max }$ : temperature at maximum weight loss occurs

The result showed about $0.97 \%$ decrease in melting temperature in treated sample of $p$-CBP as compared to the control. The melting temperature of control $p$-CBP was well supported by literature data [31]. DSC thermogram exhibited the $\Delta \mathrm{H}$ of $113.92 \mathrm{~J} / \mathrm{g}$ in control sample and $85.55 \mathrm{~J} / \mathrm{g}$ in treated sample of $p$-CBP. The result showed $24.90 \%$ decrease in $\Delta \mathrm{H}$ of treated sample as compared to the control. It is presumed that, biofield energy treatment probably supplied the energy to treated sample that is stored in the form of potential energy. Therefore, it required less energy during phase change due to the high-energy state of biofield treated samples. Previously, our group has reported that biofield energy treatment altered the value of $\Delta H$ in lead and tin powders [6]. Therefore, it is assumed that biofield energy treatment might change the intermolecular interaction of treated $p$-CBP that may lead to decrease the $\Delta \mathrm{H}$. 


\subsection{TGA-DTG Analysis}

The TGA and DTG thermogram of control and treated samples of $p$-CBP are shown in Fig. 6 and data are reported in Table 1. TGA thermogram of control $p$-CBP showed the onset temperature around $190.0^{\circ} \mathrm{C}$, while the end-set temperature was observed at $230.5^{\circ} \mathrm{C}$ with $57.36 \%$ weight loss. However, the treated $p$-CBP started losing weight around $178^{\circ} \mathrm{C}$ and the end-set was observed at $238^{\circ} \mathrm{C}$ with $58.52 \%$ weight loss (Fig. 6). The result showed the decrease in onset temperature by $6.32 \%$ and increase in end-set temperature by $3.25 \%$ in treated sample of $p$-CBP as compared to the control. The DTG thermogram exhibited the maximum thermal decomposition temperature $\left(\mathrm{T}_{\max }\right)$ at $207.51^{\circ} \mathrm{C}$ in control sample and at $206.33^{\circ} \mathrm{C}$ in treated sample of $p$-CBP. The result revealed about $0.57 \%$ decrease in $T_{\max }$ of treated sample with respect to the control.

The decrease in $\mathrm{T}_{\max }$ of treated sample might be correlated with increase in vaporization or volatilization of treated $p$ CBP after biofield treatment. It might be due to alteration in internal energy through biofield energy treatment that results into earlier vaporization as compared to the control.
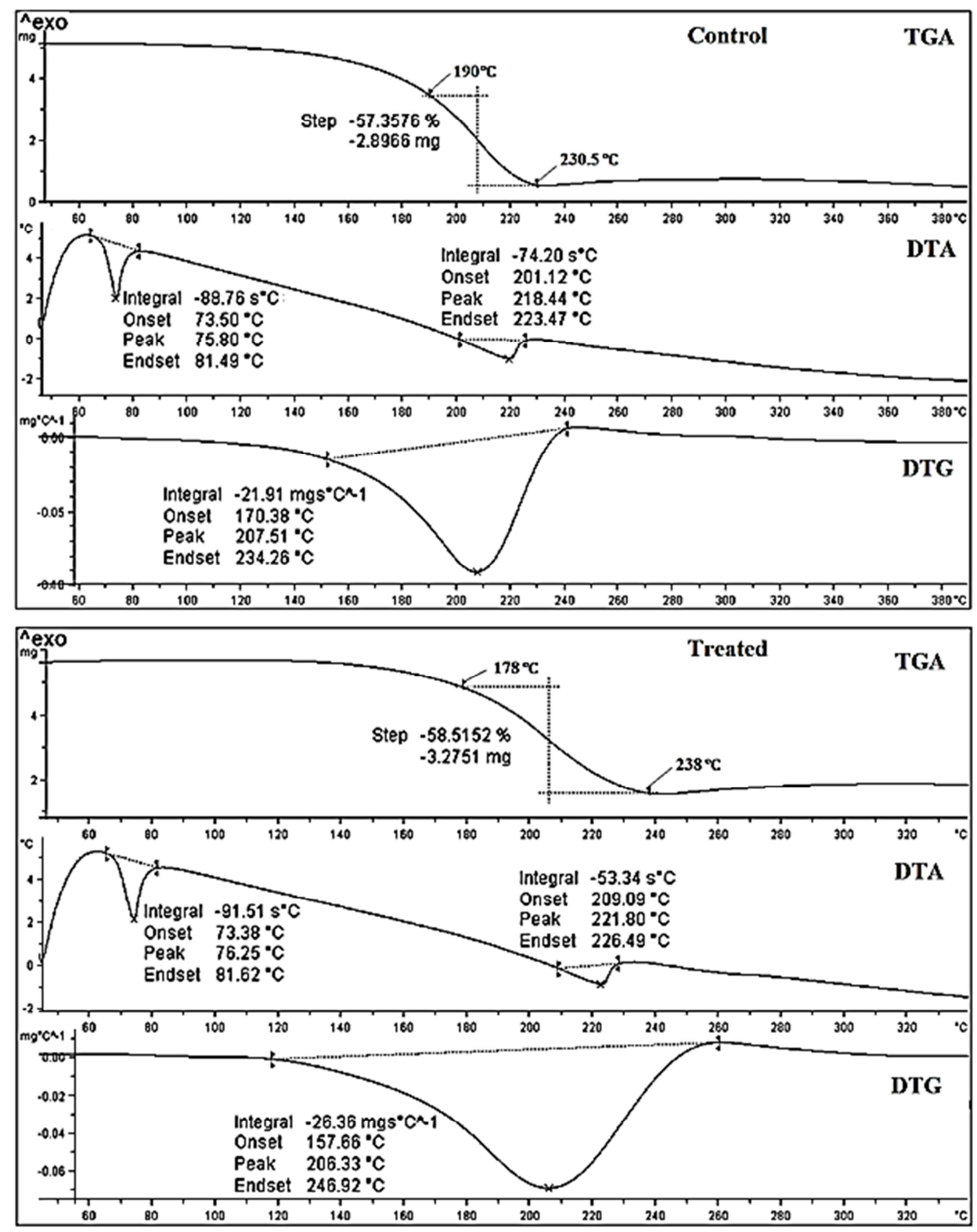

Fig. 6. TGA-DTG thermograms of control and p-chlorobenzophenone.

\subsection{FT-IR Spectroscopic Analysis}

FT-IR spectra of control and treated samples of $p$-CBP (Fig. 7) were interpreted based on the theoretically predicted wavenumber. The chemical structure of $p$-CBP showed mainly $\mathrm{C}=\mathrm{O}, \mathrm{C}=\mathrm{C}, \mathrm{C}-\mathrm{C}, \mathrm{C}-\mathrm{H}$ groups vibrational peaks. The aromatic $\mathrm{C}-\mathrm{H}$ stretching peak was assigned at $3063 \mathrm{~cm}^{-1}$ in all three samples i.e. control and treated (T1 and $\mathrm{T} 2)$. Likewise, the aromatic $\mathrm{C}-\mathrm{H}$ in-plane deformations were attributed to peaks $1089-1145 \mathrm{~cm}^{-1}$ in control and 1089-1147 $\mathrm{cm}^{-1}$ in treated (T1 and T2) samples. The C-H out of plane deformations were observed at frequency region of 729-844 
$\mathrm{cm}^{-1}$ in all three samples (control, $\mathrm{T} 1$ and $\mathrm{T} 2$ ). The vibrational peak of ketone $(\mathrm{C}=\mathrm{O})$ groups generally appears around $1715 \mathrm{~cm}^{-1}[32]$. However, in $p$-CBP, it was appeared at $1651 \mathrm{~cm}^{-1}$ in control and $\mathrm{T} 2$ samples, whereas in $\mathrm{T} 1$ sample it appeared at $1649 \mathrm{~cm}^{-1}$. This decreased wavenumber of $\mathrm{C}=\mathrm{O}$ stretching in all three samples was observed due to extended resonance effect that lower the force constant and thus wavenumber of $\mathrm{C}=\mathrm{O}$ group stretching. The aromatic $\mathrm{C}=\mathrm{C}$ stretchings were attributed to vibrational peaks observed at $1400-1585 \mathrm{~cm}^{-1}$ in control and $1400-1583 \mathrm{~cm}^{-1}$ in treated samples (T1 and T2). Similarly, the C-C stretching peak was appeared at $1284 \mathrm{~cm}^{-1}$ in control and T2 samples and at $1282 \mathrm{~cm}^{-1}$ in $\mathrm{T} 1$ sample of $p$-CBP.
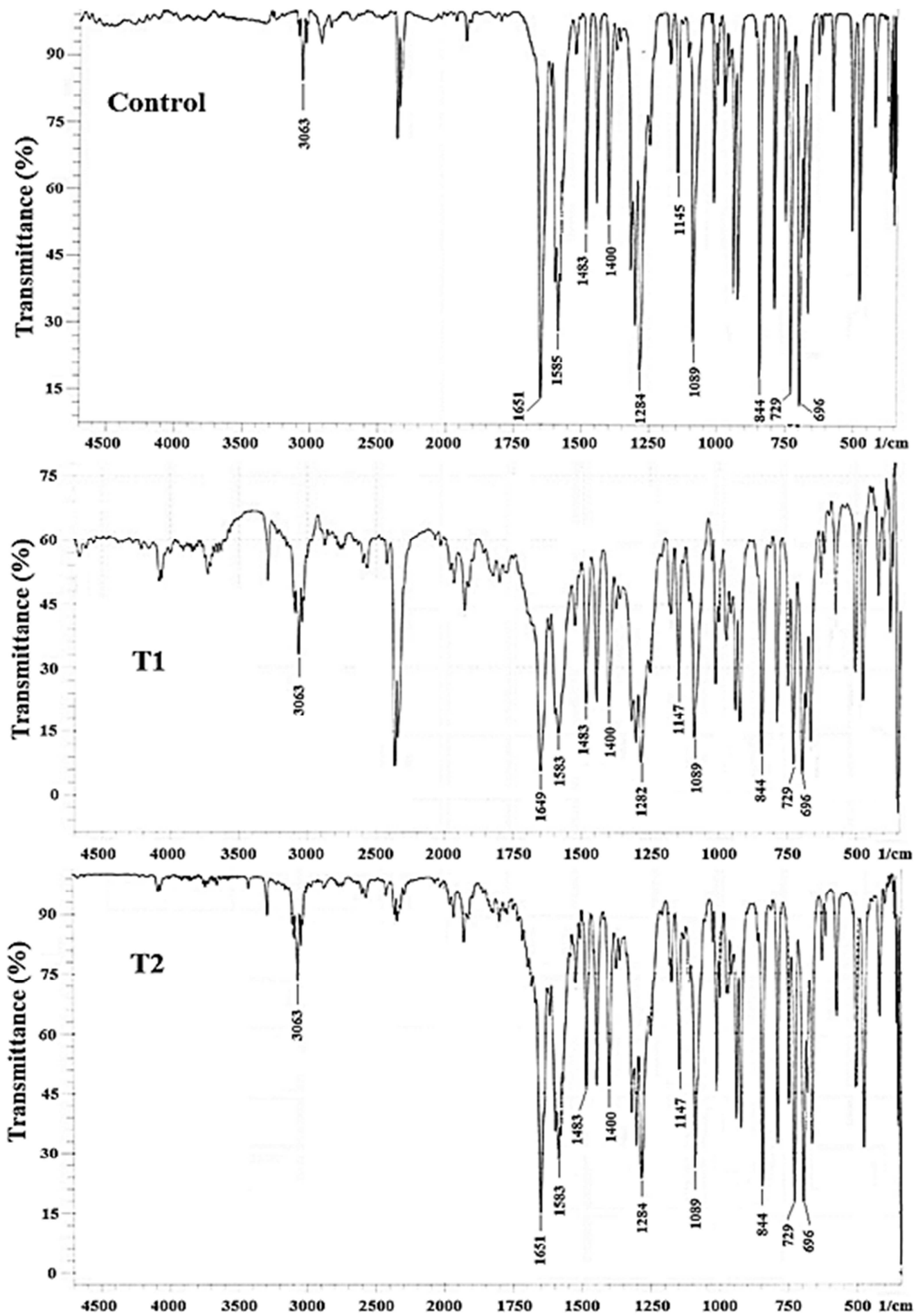

Fig. 7. FT-IR spectra of control and treated (T1 and T2) p-chlorobenzophenone.

Overall, the FT-IR result suggests that the biofield energy treatment did not exhibit the alteration in the wavenumber of any bond in treated $p$-CBP as compared to the control. 


\subsection{UV-Vis Spectroscopy}

The UV spectra of control and treated $p$-CBP are shown in Fig. 8. UV spectrum of control $p$-CBP exhibited the absorbance maxima $\left(\lambda_{\max }\right)$ at 205.0 and $257.6 \mathrm{~nm}$. A similar pattern of $\lambda_{\max }$ was observed in both the treated samples (T1 and T2) i.e. at 205.0 and $257.8 \mathrm{~nm}$ in $\mathrm{T} 1$ and 203.5 and 257.5

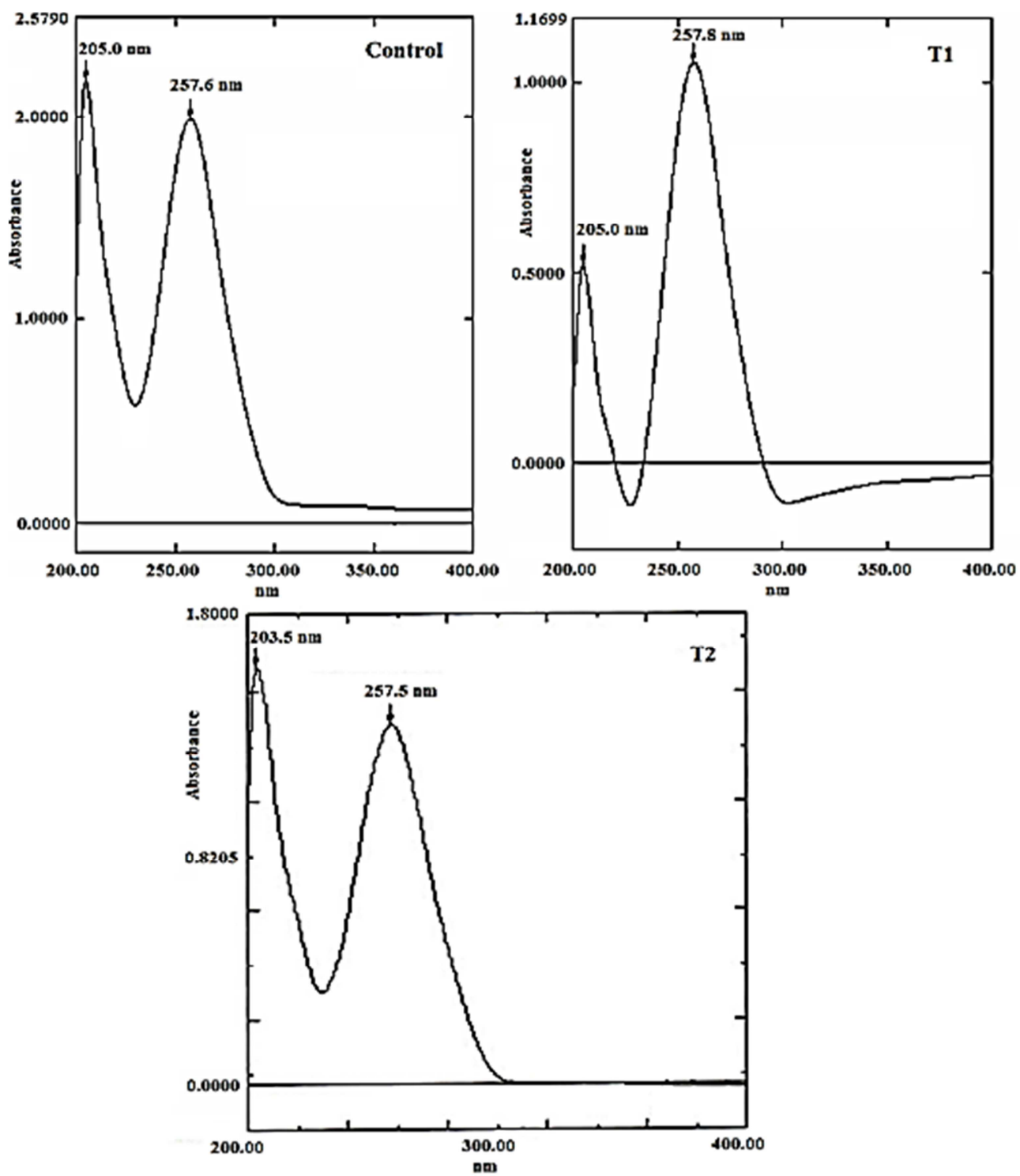

Fig. 8. UV spectra of control and treated (T1 and T2) p-chlorobenzophenone.

\section{Conclusion}

In summary, the XRD diffractogram of biofield treated $p$ CBP exhibited the increase in intensity of the XRD peaks as well as the average crystallite size $(25.93 \%)$ as compared to the control. The particle size analysis suggests the decrease in particle size of fine particles $\left(d_{10}\right)$ and increase in particle size of the large particles $\left(d_{90}\right.$ and $\left.d_{99}\right)$ with respect to the control sample. The surface area analysis showed the slight increase in the surface area of the treated $p$-CBP with respect to the control. The thermal analysis (DSC, TGA/DTG) showed a slight decrease in melting temperature and $\mathrm{T}_{\max }$. However, $\mathrm{nm}$ in T2. Overall, the UV spectral analysis suggests that biofield energy treatment may not cause any significant alterations in the $\lambda_{\max }$ of treated $p$-CBP samples with respect to the control. Altogether, the UV and FT-IR results, suggest that structural properties of treated $p$-CBP remained same as control. 


\section{Abbreviations}

$p$-CBP: para-Chlorobenzophenone;

NIH: National Institute of Health;

NCCAM: National Center for Complementary and

Alternative Medicine;

XRD: X-ray diffraction;

DSC: Differential scanning calorimetry;

TGA: Thermogravimetric analysis;

DTA: Differential thermal analysis;

DTG: Derivative thermogravimetric analysis;

FT-IR: Fourier transform infrared;

UV-Vis: Ultraviolet-visible

\section{Acknowledgement}

The authors would like to acknowledge the Trivedi Science, Trivedi Master Wellness and Trivedi Testimonials for their steady support during the work. Authors would also like to thanks the whole team of MGV pharmacy college, Nashik for providing the instrumental facility.

\section{References}

[1] Bezwada RS (2008) Chemistry of benzophenones. INDOFINE Chemical Company Hillsborough, NJ, USA. $\mathrm{http}$ ://indofinechemical.com/resources/whitepapers/Chemistry_of_Benzophenones[44WHD97].pdf.

[2] Thakur VK (2014) Lignocellulosic polymer composites: Processing, characterization, and properties. John Wiley \& Sons, MA, USA.

[3] Thenmozhi R, Claude A (2012) Rapid crystal growth of benzophenone by low temperature solution growth and its characterization. Archives Appl Sci Res 4: 898-905.

[4] Latha MS, Martis J, Shobha V, Sham Shinde R, Bangera S, et al. (2013) Sunscreening agents: A review. J Clin Aesthet Dermatol 6: 16-26.

[5] Cuquerella MC, Lhiaubet-Vallet V, Cadet J, Miranda MA (2012) Benzophenone photosensitized DNA damage. Acc Chem Res 45: 1558-1570.

[6] Trivedi MK, Patil S, Tallapragada RM (2013) Effect of bio field treatment on the physical and thermal characteristics of silicon, tin and lead powders. J Material Sci Eng 2: 125.

[7] Trivedi MK, Patil S, Tallapragada RMR (2015) Effect of biofield treatment on the physical and thermal characteristics of aluminium powders. Ind Eng Manage 4: 151.

[8] Trivedi MK, Nayak G, Patil S, Tallapragada RM, Latiyal O (2015) Evaluation of biofield treatment on physical, atomic and structural characteristics of manganese (II, III) oxide. J Material Sci Eng 4: 177.

[9] Trivedi MK, Nayak G, Patil S, Tallapragada RM, Latiyal O (2015) Studies of the atomic and crystalline characteristics of ceramic oxide nano powders after biofield treatment. Ind Eng Manage 4: 161 .

[10] Trivedi MK, Patil S, Shettigar H, Bairwa K, Jana S (2015)
Spectroscopic characterization of chloramphenicol and tetracycline: An impact of biofield. Pharm Anal Acta 6: 395.

[11] Trivedi MK, Patil S, Shettigar H, Bairwa K, Jana S (2015) Effect of biofield treatment on spectral properties of paracetamol and piroxicam. Chem Sci J 6: 98.

[12] Koithan M (2009) Introducing complementary and alternative therapies. J Nurse Pract 5: 18-20.

[13] Hok J, Tishelman C, Ploner A, Forss A, Falkenberg T (2008) Mapping patterns of complementary and alternative medicine use in cancer: an explorative cross-sectional study of individuals with reported positive "exceptional" experiences. BMC Complement Altern Med 8: 48.

[14] Aldridge D (1991) Spirituality, healing and medicine. Br J Gen Pract 41: 425-427.

[15] Cahil M (1998) Nurses handbook of complementary and alternative therapies. Springhouse, PA: Springhouse Corporation.

[16] Maxwell JC (1865) A dynamical theory of the electromagnetic field. Phil Trans R Soc Lond 155: 459-512.

[17] Rubik B (2002) The biofield hypothesis: Its biophysical basis and role in medicine. J Altern Complement Med 8: 703-717.

[18] Rivera-Ruiz M, Cajavilca C, Varon J (2008) Einthoven's String Galvanometer: The first electrocardiograph. Tex Heart Inst J 35: 174-178.

[19] Prakash S, Chowdhury AR, Gupta A (2015) Monitoring the human health by measuring the biofield "aura": An overview. IJAER 10: 27637-27641.

[20] Nayak G, Altekar N (2015) Effect of biofield treatment on plant growth and adaptation. J Environ Health Sci 1: 1-9.

[21] Trivedi MK, Bhardwaj Y, Patil S, Shettigar H, Bulbule A (2009) Impact of an external energy on Enterococcus faecalis [ATCC-51299] in relation to antibiotic susceptibility and biochemical reactions-an experimental study. J Accord Integr Med 5: 119-130.

[22] Trivedi MK, Patil S, Shettigar H, Mondal SC, Jana S (2015) Evaluation of biofield modality on viral load of Hepatitis B and $\mathrm{C}$ viruses. J Antivir Antiretrovir 7: 83-88.

[23] Shinde V, Sances F, Patil S, Spence A (2012) Impact of biofield treatment on growth and yield of lettuce and tomato. Aust J Basic Appl Sci 6: 100-105.

[24] Sances F, Flora E, Patil S, Spence A, Shinde V (2013) Impact of biofield treatment on ginseng and organic blueberry yield. Agrivita J Agric Sci 35.

[25] Patterson AL (1939) The Scherrer formula for X-ray particle size determination. Phys Rev 56: 978-982.

[26] Pavia DL, Lampman GM, Kriz GS (2001) Introduction to spectroscopy. (3rdedn), Thomson Learning, Singapore.

[27] Rashidi AM, Amadeh A (2009) The effect of saccharin addition and bath temperature on the grain size of nanocrystalline nickel coatings. Surf Coat Technol 204: 353-358.

[28] Gusain D, Srivastava V, Singh VK, Sharma YC (2014) Crystallite size and phase transition demeanor of ceramic steel. Mater Chem Phys 145: 320-326. 
[29] Gaber A, Abdel-Rahim MA, Abdel-Latief AY, Abdel-Salam MN (2014) Influence of calcination temperature on the structure and porosity of nanocrystalline $\mathrm{SnO}_{2}$ synthesized by a conventional precipitation method. Int J Electrochem Sci 9: 8195 .

[30] Trivedi MK, Nayak G, Tallapragada RM, Patil S, Latiyal O, et al. (2015) Effect of biofield treatment on structural and morphological properties of silicon carbide. J Powder Metall Min 4: 132 .

[31] Dewan A, Kakati DK (2007) Regeneration of carbonyl compounds from their oximes using Ce(IV) based phasetransfer oxidants. Indian J Chem Technol 14: 635-637.

[32] Smith BC (1998) Infrared Spectral Interpretation: A systematic approach. CRC Press. 